\title{
Fractions and isolated compounds from Oxyanthus speciosus subsp. stenocarpus (Rubiaceae) have promising antimycobacterial and intracellular activity
}

Abimbola O. Aro', Jean P. Dzoyem ${ }^{1,2}$, Maurice D. Awouafack ${ }^{1,3}$, Mamoalosi A. Selepe ${ }^{4}$, Jacobus N. Eloff ${ }^{1 *}$ (i) and Lyndy J. McGaw'

\begin{abstract}
Background: Tuberculosis is a deadly disease caused by Mycobacterium species. The use of medicinal plants is an ancient global practice for the treatment and prevention of diverse ailments including tuberculosis. The aim of this study was to isolate and characterize antimycobacterial compounds by bioassay-guided fractionation of the acetone leaf extract of Oxyanthus speciosus.

Methods: A two-fold serial microdilution method was used to determine the minimum inhibitory concentration (MIC) against mycobacteria. Cytotoxicity and nitric oxide inhibitory activity of the isolated compounds was determined to evaluate in vitro safety and potential anti-inflammatory activity. Intracellular efficacy of the crude extract against Mycobacterium-infected macrophages was also determined.

Results: Two compounds were isolated and identified as lutein (1) and rotundic acid (2). These had good antimycobacterial activity against the four mycobacteria tested with MIC values ranging from 0.013 to $0.1 \mathrm{mg} / \mathrm{mL}$. Rotundic acid had some cytotoxicity against C3A human liver cells. Lutein was not cytotoxic at the highest tested concentration $(200 \mu \mathrm{g} / \mathrm{mL})$ and inhibited nitric oxide production in RAW 264.7 macrophages by $94 \%$ at a concentration of $25 \mu \mathrm{g} / \mathrm{mL}$. The acetone crude extract $(120 \mu \mathrm{g} / \mathrm{mL})$ of $O$. speciosus had intracellular antimycobacterial activity, reducing colony forming units by more than $90 \%$, displaying bactericidal efficacy in a dose and time-dependent manner.

Conclusion: This study provides good proof of the presence of synergism between different compounds in extracts and fractions. It is also the first report of the antimycobacterial activity of lutein and rotundic acid isolated from Oxyanthus speciosus. The promising activity of the crude extract of $O$. speciosus both in vitro and intracellularly in an in vitro macrophage model suggests its potential for development as an anti- tuberculosis (TB) herbal medicine.
\end{abstract}

Keywords: Oxyanthus speciosus, Mycobacterium tuberculosis, Rotundic acid, Lutein, Intracellular, Nitric oxide inhibition

\footnotetext{
*Correspondence: kobus.eloff@up.ac.za

'Department of Paraclinical Sciences, Faculty of Veterinary Science, University

of Pretoria, Private Bag X04, Onderstepoort 0110, South Africa

Full list of author information is available at the end of the article
}

(c) The Author(s). 2019 Open Access This article is distributed under the terms of the Creative Commons Attribution 4.0 International License (http://creativecommons.org/licenses/by/4.0/), which permits unrestricted use, distribution, and reproduction in any medium, provided you give appropriate credit to the original author(s) and the source, provide a link to the Creative Commons license, and indicate if changes were made. The Creative Commons Public Domain Dedication waiver (http://creativecommons.org/publicdomain/zero/1.0/) applies to the data made available in this article, unless otherwise stated. 


\section{Background}

Tuberculosis, caused by organisms belonging to the $\mathrm{Myco}$ bacterium tuberculosis complex, has re-emerged as a major disease of global importance University of Pretoria [1]. The innovation of tuberculin in 1890, Bacillus-Calmette Guerin (BCG) vaccine in 1908 and discoveries of antimycobacterial drugs in 1943 brought great hope for the eradication of this deadly disease until the pandemic of HIV/AIDS and upsurge of resistant strains (multi-drug, extensive-drug and total-drug resistant) ravaged humankind [2]. To effectively combat these drug resistant cases, new TB drugs with novel modes of action are desperately needed. After a long period of inactivity, there has been an increase in the number of new antimycobacterial drugs in the pipeline with the recent approval of bedaquiline and delamanid by the US food and drug administration (FDA) for the treatment of drug resistant TB [3]. However, these drugs are only used as a last resort due to their reported toxicity [4]. Therefore, novel, efficacious and safe anti-TB drugs that can shorten the duration of therapy, with fewer toxic effects to promote patient compliance is urgently needed. Drugs able to combat MDR, XDR and TDR-TB strains, active against latent TB and able to act in synergism with co-administered anti-TB drugs, are urgently required. Currently, there are increasing numbers of drug candidates in the optimization stage, preclinical development, phase II and phase III clinical trials. However, the low number of drug candidates in the phase I stage is worrisome in the eventuality of failure of advanced drug candidates [3]. The efforts of the TB Alliance are geared towards development of novel anti-TB drugs; preliminary screening of natural products for drug discovery is imperative to increase the number of drug candidates in the pipeline [5]. Furthermore, an interdisciplinary approach is needed for the discovery of new chemical molecules against both active and latent forms of TB [4].

Nitric oxide (NO) is a free radical involved in many biological processes with the ability to enhance bactericidal and tumoricidal activities of activated macrophages [6]. Excessive production of reactive oxygen species (ROS) generated can lead to inflammation by enhancing the release of cytokines and activation of enzymes such as lipoxygenases (LOXs) from inflammatory cells. LOX has been linked to several inflammatory diseases including TB [7]. The role played by the reactive oxygen and nitrogen intermediates during TB infection is not fully understood, though it is known that hydrogen peroxide produced by macrophages activated by cytokines has a mycobactericidal activity [8]. Hence, the overproduction of reactive oxygen and nitrogen intermediates could lead to inflammation [9]. An effective immune response to $M$. tuberculosis plays a crucial role in determining the establishment of disease [10]. However, the intricate interaction of $M$. tuberculosis with the immune system leads to the release of a vast array of cytokines by diverse cell types in response to infection [11]. Macrophages are target cells for mycobacterial infections and are solely responsible for intracellular killing of mycobacteria, and this is largely dependent on the cytokine environment [12].

It is well-established that natural products contribute significantly to the discovery and derivation of lead compounds and development of drugs that are introduced into the market. Interestingly, $65 \%$ of antibacterials approved for use between 1981 and 2010 were natural products or their derivatives, including currently employed TB drugs, for example rifampicin and the aminoglycosides [13]. Natural products found in higher plants are important sources of therapeutic and pharmacological agents, and different research groups across the globe are screening different plants for their biological activities [14, 15]. Large anti-TB bioprospecting screening programmes are currently in progress, and there is a renewed interest in natural sources for finding novel antimycobacterials [16]. Selecting plants that have shown excellent in vitro activity and subjecting them to further in vivo efficacy and toxicity studies may lead to development of effective and safer drugs against infectious diseases [17].

The Rubiaceae family contains 611 genera but only 48 genera have been studied and have good biological activity against different pathogenic bacterial strains [18]. There are 61 genera and 228 species native or naturalized in southern Africa [19]. The Rubiaceae family has played a significant role in drug discovery by providing molecules used as templates for the development of drugs [19]. Members of this family produce a large diversity of substances such as iridoids, indole alkaloids, anthraquinones, terpenoids (diterpenes and triterpenes), flavonoids and other phenolic derivatives [20]. This family is also characterised by the presence of other natural products such as iridoids (a group of monoterpenoids), methylxanthines (such as theobromine and theophylline) and anthranoids [21]. McGaw et al. [22] documented the anti-tubercular activity of close to 180 species of some medicinal plants in southern Africa used for TB-related complaints; however, only 4 species from the Rubiaceae family were reported.

A previous study reported the activity of acetone leaf extracts of 537 South African tree species against eight important microorganisms including Mycobacterium smegmatis with the aim of finding extracts with high activity and predicting which taxa could have a high priority for further investigation [23]. Six species from the Rubiaceae family had interesting activity against $M$. smegmatis and were investigated in more detail against pathogenic Mycobacterium species as well. Acetone leaf extracts from Oxyanthus speciosus had promising efficacy against non-pathogenic and pathogenic mycobacteria [24]. The aim of this study was to identify the antimycobacterial compounds by bioassay-guided fractionation of the acetone crude leaf extract of Oxyanthus 
speciosus. The cytotoxicity of fractions and isolated compounds as well as the nitric oxide inhibitory activity of the isolated compounds were determined while the intracellular activities of the crude extract were evaluated.

\section{Methods}

\section{Plant material}

The leaves of Oxyanthus speciosus were collected in February 2013 in the Lowveld Botanical Garden, Nelspruit, Mpumalanga, South Africa based on the labels of the trees. Plant material was identified by Magda Nel and a voucher specimen was deposited at the HGWJ Schweickerdt Herbarium of the University of Pretoria (PRU) under the voucher number PRU 120078. The leaves were air dried at room temperature, ground to a fine powder in a Macsalab mill (model 2000 LAB Eriez) and stored in closed glass containers in the dark until needed.

\section{Extraction, fractionation and isolation}

The air-dried and powdered leaves of O. speciosus (170 g) were extracted in acetone $(1 \mathrm{l})$ for $24 \mathrm{~h}$ (repeated thrice) to give a crude extract $(40 \mathrm{~g})$ after filtration and removal of the solvent at $40{ }^{\circ} \mathrm{C}$ using a rotary evaporator. Part of the crude extract $(37 \mathrm{~g})$ was subjected to silica gel column chromatography (CC) eluting with combinations of $n$-hexane (hex), ethyl acetate (EtOAc), and methanol $(\mathrm{MeOH})$ in increasing polarity to afford 64 fractions of $500 \mathrm{~mL}$ each. Based on the similarity on the chromatograms from the thin layer chromatography (TLC) analyses, the collected samples were combined into eleven main fractions: $F_{1}$ [hex/EtOAc (100:0 and 90:10), $750 \mathrm{mg}$ ], $F_{2}$ [hex/EtOAc (90:10 and 80:20), 1.16 g], $F_{3}$ [hex/EtOAc (80:20 and 70:30), $550 \mathrm{mg}$ ], $\mathrm{F}_{4}$ [hex/ EtOAc (70:30), $1.14 \mathrm{~g}$ ], $\mathrm{F}_{5}$ [hex/EtOAc (70:30 and 60:40), $610 \mathrm{mg}$ ], $\mathrm{F}_{6}$ [hex/EtOAc (50:50), $120 \mathrm{mg}$ ], $\mathrm{F}_{7}$ [hex/EtOAc (40:60), $160 \mathrm{mg}$ ], $\mathrm{F}_{8}$ [hex/EtOAc (20:80 and 0:100), 300 $\mathrm{mg}$ ], $\mathrm{F}_{9}$ [EtOAc/MeOH (80:20), $30 \mathrm{mg}$ ], $\mathrm{F}_{10}$ [EtOAc/
$\mathrm{MeOH}$ (50:50),10.49 g], and $\mathrm{F}_{11}$ [EtOAc/MeOH (30:70, $0: 100), 11.03 \mathrm{~g}]$. Based on the bioassay-guided activity, fractions $\mathrm{F} 1$ to $\mathrm{F} 4$ and F9, to F11 did not have as many and as active antimycobacterial compounds separated by TLC in bioautography (Fig. 1) as fractions F5, F6 to F8, and were not further investigated. Fractions F6 $(80 \mathrm{mg})$ and F7 (120 mg) were individually subjected to repeated Sephadex LH-20 chromatography to afford compound 1 $(6.4 \mathrm{mg})$. Fraction F8 $(270 \mathrm{mg})$ was subjected to further silica gel column chromatography for purification using isocratic solvent system of $n$-hexane:acetone (7:3) to afford 48 sub-fractions of $50 \mathrm{~mL}$ each that were combined to main sub-fractions based on their TLC profiling. Sub-fractions F8 (12-13, 14-21, 22-37, and 38-48) yielded compound 2 (white powder, $50 \mathrm{mg}$ ). Fraction F5 (570 mg) was subjected to another silica gel column chromatography for purification using $n$-hexane: EtOAc in a gradient polarity eluent system. Due to the complex mixture of constituents and the small quantity of the material no compound was isolated.

\section{General experimental procedures}

The ${ }^{1} \mathrm{H}$ and ${ }^{13} \mathrm{C}$ NMR spectra were recorded with a Varian and Bruker (Avance III) spectrometer at $400 \mathrm{MHz}$ for $1 \mathrm{H}$ and $100 \mathrm{MHz}$ for ${ }^{13} \mathrm{C}$. Chemical shifts $(\delta)$ are quoted in parts per million ( $\mathrm{ppm}$ ) relative to the internal standard tetramethylsilane (TMS) or residual solvent peak (acetone- $d_{6}$ : $\delta_{\mathrm{H}} 2.05$ and $\left.\delta_{\mathrm{C}} 29.84\right)$. The high-resolution mass spectra were recorded on a time-of-flight Waters Synapt high definition MS using electrospray ionization in the positive or negative mode. Column chromatography was performed on MN silica gel $60(0.063-0.2 \mathrm{~mm} / 70-230)$ mesh. Precoated plates of thin layer chromatography (TLC) silica gel 60 F254 (Merck, Germany) were used for monitoring fractions and spots were detected with UV light (254 and 365 $\mathrm{nm}$ ) and then sprayed with vanillin-sulphuric acid spray

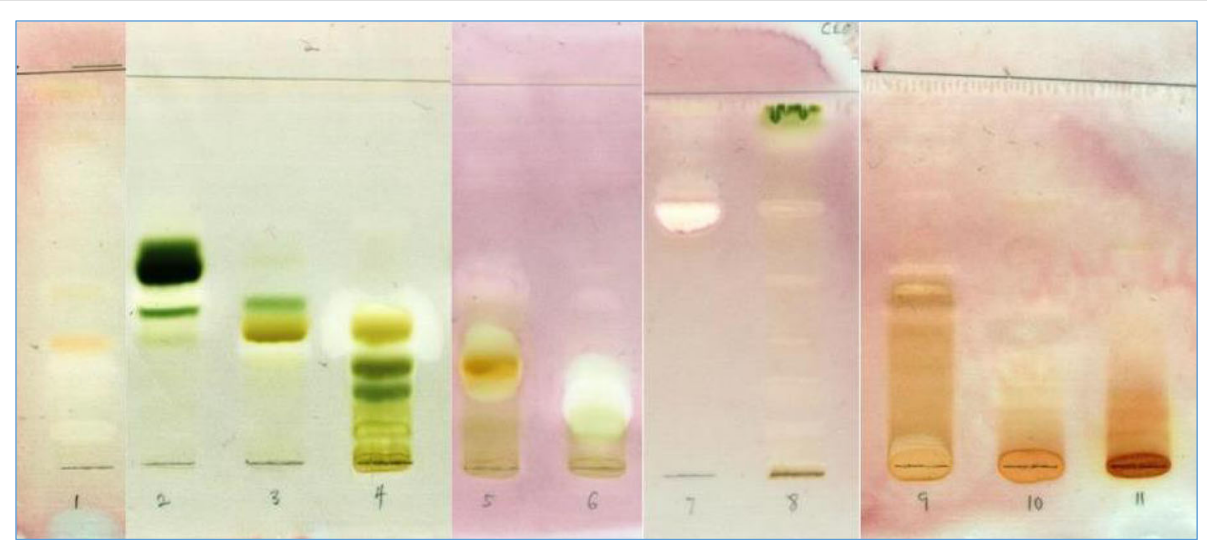

Fig. 1 Bioautography of fractions against M. smegmatis showing clear bands of antimycobacterial activity in chromatograms developed in chloroform/ethyl acetate/formic acid (CEF) 
reagent followed by heating at $110{ }^{\circ} \mathrm{C}$ for about three min until appropriate colour development.

Compound 1: Orange powder, molecular formula: $\mathrm{C}_{40} \mathrm{H}_{56} \mathrm{O}_{2}$, ESIMS (+) m/z: $429\left(\left[\mathrm{M}-\mathrm{C}_{9} \mathrm{H}_{15} \mathrm{O}\right]+\right) ; 1 \mathrm{H} \mathrm{NMR}$ (100 MHz, methanol-d4) $\delta \mathrm{H}: 1.08$ (H3-16), 1.08 (H3-17), 1.74 (H3-18), 1.97 (H3-19), 1.97 (H3-20), 1.01 (H3-16'), $0.86\left(\mathrm{H} 3-17^{\prime}\right), 1.63\left(\mathrm{H} 3-18^{\prime}\right), 1.92\left(\mathrm{H} 3-19^{\prime}\right)$, and 1.26 (H3-20'). 13C NMR (400 MHz, methanol-d4) $\delta \mathrm{C}: 65.9$ (C-3), 65.0 (C-3'), 54.9 (C-6'), 48.4 (C-2), 42.5 (C-4), 44.6 (C-2'), 28.7 (C16), 30.2 (C-17), 21.6 (C-18), 12.7 (C-19), 12.7 (C-20), 24.3 (C-16'), 29.5 (C-17'), 22.8 (C-18'), 13.1 (C-19'), $12.8\left(\mathrm{C}-20^{\prime}\right)$.

Compound 2: White powder consisting of a mixture of closely related ursine-type triterpenes; ESIMS $(+) \mathrm{m} /$ z: $511.3397[\mathrm{M}+\mathrm{Na}]+$ for $\mathrm{C}_{30} \mathrm{H}_{48} \mathrm{O}_{5} \mathrm{Na}$, Calcd 511.3399; $1 \mathrm{H}$ NMR $(400 \mathrm{MHz}$, acetone-d6) $\delta \mathrm{H}: 5.28(1 \mathrm{H}, \mathrm{brt}, 3.7$ $\mathrm{Hz}, \mathrm{H}-12), 3.56-3.62(1 \mathrm{H}, \mathrm{m}, \mathrm{H}-3), 3.62(1 \mathrm{H}, \mathrm{d}, 10.5 \mathrm{~Hz}$, $\mathrm{H}-23 \mathrm{a}), 3.32(1 \mathrm{H}, \mathrm{d}, 10.5 \mathrm{~Hz}, \mathrm{H}-23 \mathrm{~b}), 2.55(1 \mathrm{H}$, brs, $\mathrm{H}-18), 0.76$ (3H, s, H3-24), 0.79 (3H, s, H3-25), 0.95 (3H, d, $6.8 \mathrm{~Hz}, \mathrm{H} 3-30), 0.97$ (3H, s, H3-26), 1.20 (3H, s, H3-29), 1.35 (3H, s, H3-27);

\section{GC-MS analysis of leaf extracts of Oxyanthus speciosus}

The powdered plant material was extracted with acetone and analyzed using GC-MS LECO Pegasus 4D GC-TOFMS (LECO Africa (Pty) Ltd., South Africa). The data were obtained on an Elite-1(100\% Dimethyl poly siloxane) GC column Rxi-5SilMS $30 \mathrm{~m} \times 0.25 \mathrm{~mm}$ ID $\times 0.2 \mu \mathrm{m}$ film thickness (Restek, Bellefonte, PA, USA). Spectroscopic detection by GC-MS involved an electron ionization system which utilized high-energy electrons $(70 \mathrm{eV})$. Pure helium gas (Afrox, South Africa) was used as the carrier gas with a constant flow rate of $1 \mathrm{~mL} / \mathrm{min}$. Oven temperature was held for $3 \mathrm{~min}$ with $5 \mathrm{~min}$ solvent delay programmed at $40^{\circ}$ $\mathrm{C}$ and held isothermally at $300^{\circ} \mathrm{C}$ for $5 \mathrm{~min}$. An aliquot of $1 \mu \mathrm{L}$ of acetone solution of the sample was injected in a spitless mode (spitless time 30s) and split ratio of 10:1 with the injector temperature at $250^{\circ} \mathrm{C}$ and $\mathrm{MS}$ transfer temperature line set at $280^{\circ} \mathrm{C}$. Ion source temperature was maintained at $230^{\circ} \mathrm{C}$. A scan interval of $0.5 \mathrm{~s}$ and mass acquisition fragments ranging from 40 to $550 \mathrm{Da}$ was maintained with data acquisition rate of 10 spectra/ s. The relative quantity of the compounds present in the extracts was expressed as a percentage based on the peak area produced in the chromatogram. Tentative identification of the bioactive constituents was based on the comparison of their retention time with those of standards samples and by matching the spectral fragmentation patterns against commercial library mass spectra.

\section{Antimycobacterial activity assay} Mycobacterial culture and inoculum preparation

Antimycobacterial activity was tested against four mycobacterial species including three non-pathogenic, fast-growing strains: Mycobacterium smegmatis (ATCC 1441) obtained from the American Type Culture Collection, Mycobacterium aurum (NCTC 10437) obtained from the National Collection of Type Cultures (UK Laboratory), Mycobacterium fortuitum (ATCC 6841) and one pathogenic strain Mycobacterium tuberculosis field strain (TB 8104) obtained from the Bacteriology Section, Agricultural Research Council-Onderstepoort Veterinary Institute, South Africa. Cultures were maintained as previously described [24].

\section{Cytotoxicity assay}

The cytotoxicity of the crude plant extract, fractions and isolated compounds were tested against C3A human liver cells (purchased from ATCC, CRL-10741) using the 3-(4,5-dimethylthiazol)-2,5-diphenyl tetrazolium bromide (MTT) assay [25] with slight modifications [26].

\section{Nitric oxide (NO) inhibitory production}

The NO production inhibitory activity of Oxyanthus speciosus crude extract and isolated compounds was evaluated in the LPS-activated mouse macrophage cell line RAW 264.7 as previously described [27]. Briefly, the percentage of nitric oxide released from the macrophages was assessed by determining the nitrite concentration in culture supernatant using Griess reagent. Post $24 \mathrm{~h}$ incubation, $100 \mu \mathrm{L}$ of supernatant from each well of cell culture plates was transferred into 96-well microtitre plates and equal volume of Griess reagent was added. A microtiter plate reader (SpectaMax 190 Molecular devices) was used for reading the absorbance after $10 \mathrm{~min}$ at $550 \mathrm{~nm}$. The concentrations of nitrite were calculated from regression analysis using serial dilutions of sodium nitrite as a standard. Validity of the assays was shown by using untreated cells as negative control, LPS-stimulated cells as positive control and additionally a cell group as reduction control group with LPS-stimulated cells, co-incubated together with quercetin used as an inhibitor of NO.

\section{Intracellular assay of the crude acetone extracts of Oxyanthus speciosus}

The mouse macrophage cell line RAW 264.7 (ATCC TIB-71) was used to study the activity of samples against intracellular M. fortuitum [28, 29]. Cells were cultured in Dulbecco's Modified Eagle Medium (D-MEM) supplemented with $10 \% \mathrm{FBS}$ and $1 \%$ glutamine, at $37^{\circ} \mathrm{C}$ and $5 \%$ $\mathrm{CO}_{2}$. Twenty $\mathrm{mL}$ of media (D-MEM) were dispensed into a $75-\mathrm{cm}^{3}$ flask. Cells were detached from the flask by using a cell scraper, centrifuged at $1000 \mathrm{rpm}$ for $5 \mathrm{~min}$, suspended in $10 \mathrm{~mL}$ media and counted, after which the cell suspension was seeded in a 96-well microtitre plate at a density of $10^{5}$ cells $/ \mathrm{mL}$ and incubated at $37^{\circ} \mathrm{C}$ and $5 \% \mathrm{CO}_{2}$ for $24 \mathrm{~h}$. $M$. fortuitum grown in Middlebrook $7 \mathrm{H} 10$ broth was diluted with the cell culture medium (without antibiotics) to a final concentration of $10^{5} \mathrm{CFU} / \mathrm{mL}$ and added to each 
well to give a multiplicity of infection (MOI) of 3 and incubated for 4 to $10 \mathrm{~h}$ at $37^{\circ} \mathrm{C}$ in $5 \% \mathrm{CO}_{2}$ for the cells to take up bacteria. Extracellular bacteria were removed by washing the plate with PBS and then $100 \mu \mathrm{L}$ of drug-containing medium was added to each well followed by incubation under the same conditions as above. After 2, 4 and 6 days, cells from control and treated wells were lysed using $0.25 \%$ sodium dodecyl sulphate and sonicated at $1.5 \mathrm{~W}$ for $15 \mathrm{~s}$. Then five dilutions $\left(10^{0}-10^{5}\right)$ were prepared and $100 \mu \mathrm{L}$ of each dilution were spread on Middlebrook $7 \mathrm{H} 11$ agar plates and incubated at $37^{\circ} \mathrm{C}$ for 7 to 10 days until colonies were visible (4-6 days) and the number of $\mathrm{CFU} / \mathrm{mL}$ was determined. A plant extract was considered bactericidal if it significantly reduced the colony forming units in the test samples compared with the control. Rifampicin serially diluted from $4 \mathrm{mg} / \mathrm{mL}(\mathrm{MIC}=50 \mu \mathrm{g} / \mathrm{mL}$ ) was included as the control bactericidal compound.

\section{Statistical analysis}

All experiments were conducted in triplicate and values expressed as mean \pm standard deviation. Differences between values were assessed for significance using analysis of variance using Microsoft excel and results were compared using the Fisher's least significant difference (LSD) at $5 \%$ significance level.

\section{Results}

\section{Structure elucidation and GC-MS}

The acetone leaf crude extract of $O$. speciosus was subjected to bioassay-guided fractionation using open column chromatography and bioautography to determine the number of antimycobacterial compounds present [30] (Fig. 1). Briefly, the eluting solvent was removed from the chromatogram in a flow of air at room temperature, chromatograms were sprayed with a dense $M$. smegmatis culture, incubated overnight and sprayed with $0.2 \mathrm{mg} / \mathrm{ml} \mathrm{p}$-iodonitrotetrazolium violet to indicate $\mathrm{Rf}$ values of compounds that inhibited mycobacterial growth. The MIC of each fraction was also determined. Eleven main fractions were obtained. Two known compounds, lutein (1) [31-33] and rotundic acid (2) [34], were isolated (Fig. 2). The structures of these compounds were identified after analysis of their NMR data and by comparison with those reported in the literature. The presence of lutein (1) and rotundic acid (2) are reported from Oxyanthus speciosus for the first time to the best of our knowledge. The compositions of the crude extract constituents were established by GC-MS analyses (Table 1). The compounds present in the acetone extracts of $O$. speciosus were detected by gas chromatography (GC) and identified by mass spectrometry (MS). The GC-MS analyses revealed 17 compounds tentatively identified and confirmed with the library match of $70 \%$ similarity and above based on the peak area, retention time and molecular formula. To the best of our knowledge, no chemical or biological investigations have been carried out on this species as yet.

\section{Antimycobacterial activity}

The antimycobacterial activity of fractions and compounds from Oxyanthus speciosus was determined against three non-pathogenic and one pathogenic Mycobacterium species and the results are given as minimum inhibitory concentration (MIC) in $\mathrm{mg} / \mathrm{mL}$. An extract or fraction can be said to have a significant activity if the MIC value is $100 \mu \mathrm{g} / \mathrm{mL}$ or lower, moderate if $100<$ MIC $\leq 625$ and weak if MIC is $>625 \mu \mathrm{g} / \mathrm{mL}$ [35]. An isolated compound is said to possess significant antimicrobial activity if the MIC value is $\leq 10 \mu \mathrm{g} / \mathrm{mL}$, moderate if $10<$ MIC $\leq 100 \mu \mathrm{g} / \mathrm{mL}$ and weak if MIC is $>100 \mu \mathrm{g} / \mathrm{mL}$ [36]. The fractions had different degrees of activity against the four mycobacteria, ranging from excellent to weak with MIC values between $0.039 \mathrm{mg} / \mathrm{mL}$ and $2.5 \mathrm{mg} / \mathrm{mL}$ (Table 2). Fractions 9 and 10 had the best MIC value of $0.039 \mathrm{mg} / \mathrm{mL}$ while fractions $2,3,4,5,8$ and 11 had moderate activity with MIC values ranging from 0.156 $\mathrm{mg} / \mathrm{mL}$ to $0.625 \mathrm{mg} / \mathrm{mL}$. Lutein and rotundic acid had moderate activity against the four tested mycobacteria with MIC values ranging from 12.5 to $100 \mu \mathrm{g} / \mathrm{mL}$.

Total activity (TA) of the fractions was calculated by dividing the total mass $(\mathrm{mg})$ of the fraction by the MIC value $(\mathrm{mg} / \mathrm{mL})$ [35]. By dividing mass in $\mathrm{mg}$ by MIC in $\mathrm{mg} / \mathrm{mL}$ the units of the result are in $\mathrm{mL}(\mathrm{mg} / \mathrm{mg} / \mathrm{ml}=$ $\mathrm{ml}$ ). Because the total activities of the fractions are so high, it is divided by 1000 and presented in L. The values obtained indicate the volume to which the active constituent present in the fraction can be diluted and still inhibit the growth of the tested organisms. $F_{10}$ and $F_{11}$ had the highest total activity against the tested organisms while $\mathrm{F}_{6}$ and $\mathrm{F}_{7}$ had the lowest total activity (Table 1). Also, TA calculation detects loss or gain in biological activity at each step of fractionation, by processes such as photo-oxidation or synergistic interaction between the plant fractions or compounds [35]. The crude acetone extract of Oxyanthus speciosus had TA values of 383and $0.063 \mathrm{~L}$ against $M$. smegmatis, $M$. aurum and $M$. tuberculosis (8104) respectively [24]. Total activity can also be used to select the most promising plant species to investigate [37]. In such a case the quantity in mg extracted $(\mathrm{mg} / \mathrm{mL})$ is divided by the MIC $(\mathrm{mg} / \mathrm{mL})$ providing a TA in $\mathrm{mL} / \mathrm{mg}$. Oxyanthus speciosus subsp. Stenocarpus extracts were selected based on the TA. Total activity can also indicate if activity was lost or gained during the fractionation process [35]. The TA of the fractions ranged from 0.09 to $269 \mathrm{~L}$. The acetone fraction had a total activity of $1771.1 \mathrm{~L}$ before it was further fractionated by column chromatography. The last two fractions had the highest total activity indicating 
<smiles>CC1=C[C@@H](O)CC(C)(F)C1/C=C/C(C)=C/C=C/C(C)=C/C=C/C=C(C)/C=C/C=C(C)/C=C/C1=C(C)C[C@@H](O)CC1(C)P</smiles>

1

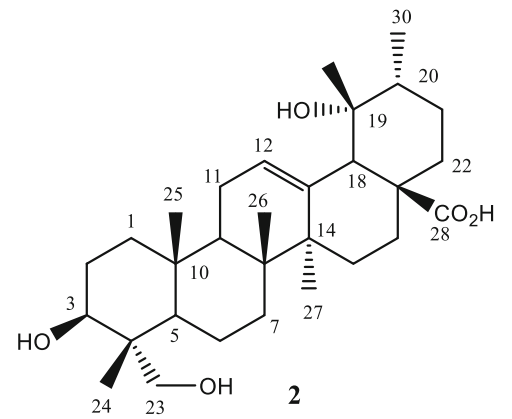

Fig. 2 Chemical structures of lutein (1) and rotundic acid (2) isolated from O. speciosus

that the active compounds were relatively non-polar. The total activity of the fractions against M. smegmatis, $M$. aurum, M. tuberculosis (8104) and $M$. fortuitum were $11.7,13.5,7.1$. and 49.0 L respectively (Table 2 ).

\section{Cytotoxic activity and inhibition of NO production}

Fractions $\mathrm{F}_{9}$ and $\mathrm{F}_{10}$ had some degree of toxicity against C3A human liver cells while other fractions had relatively moderate cytotoxicity against this cell line. Lutein was not cytotoxic even at the highest tested concentration $(200 \mu \mathrm{g} /$
$\mathrm{mL}$ ) while rotundic acid was relatively cytotoxic to the tested cell line with an $\mathrm{LC}_{50}$ value of $33 \mu \mathrm{g} / \mathrm{mL}$. Lutein also had low toxicity against RAW 264.7 macrophages, supporting the results found by Rafi and Shafaie [38]. The higher the selectivity index the higher the potential safety of the extract or compound when used in vivo. The selectivity index (SI) value obtained in this study for the fractions ranged from 0.02 to 3.27 with fraction $\mathrm{F}_{8}$ having the highest value against $M$. smegmatis (Table 3). Most of the fractions appeared to be more toxic to the human cells than to the

Table 1 Bioactive compounds detected in the acetone crude extract of Oxyanthus speciosus

\begin{tabular}{|c|c|c|c|c|c|}
\hline $\mathrm{S} / \mathrm{N}$ & Compound & $\mathrm{RT}(\mathrm{min})$ & Molecular formula & MW & $\%$ Peak Area \\
\hline 1 & 2-Methylthiophene & 12.03 & $\mathrm{C}_{5} \mathrm{H}_{6} \mathrm{~S}$ & 98 & 0.03 \\
\hline 2 & 2-Methyl-penten-3-yne & 1.33 & $\mathrm{C}_{6} \mathrm{H}_{8}$ & 80 & 1.63 \\
\hline 3 & 4-(Methylenecyclopropyl)-butyraldehyde or 4-(2-Methylenecyclopropyl) butanal & 11.89 & $\mathrm{C}_{8} \mathrm{H}_{12} \mathrm{O}$ & 124 & 7.99 \\
\hline 4 & Methylcyclooctane & 11.81 & $\mathrm{C}_{9} \mathrm{H}_{18}$ & 126 & 0.34 \\
\hline 5 & O-Decylhydroxylamine & 7.26 & $\mathrm{C}_{10} \mathrm{H}_{23} \mathrm{NO}$ & 173 & 3.92 \\
\hline 6 & 4H-1,3,2-Dioxaborin, 6-ethenyl-2-ethyl-4-methyl-4-(2-methylpropyl)- & 21.57 & $\mathrm{C}_{12} \mathrm{H}_{21} \mathrm{BO}_{2}$ & 208 & 0.10 \\
\hline 7 & Phenyl 4-methoxybenzoate & 19.62 & $\mathrm{C}_{14} \mathrm{H}_{12} \mathrm{O}_{3}$ & 228 & 0.00007 \\
\hline 8 & 3-Octadecyne & 12.24 & $\mathrm{C}_{18} \mathrm{H}_{34}$ & 250 & 0.87 \\
\hline 9 & 2-Methylheptadecane & 15.58 & $\mathrm{C}_{18} \mathrm{H}_{38}$ & 254 & 1.94 \\
\hline 10 & Nonadecane & 11.88 & $\mathrm{C}_{19} \mathrm{H}_{40}$ & 268 & 7.99 \\
\hline 11 & Neophytadiene & 24.67 & $\mathrm{C}_{20} \mathrm{H}_{38}$ & 278 & 0.44 \\
\hline 12 & Phytol & 14.75 & $\mathrm{C}_{20} \mathrm{H}_{40} \mathrm{O}$ & 296 & 0.73 \\
\hline 13 & 1-lodo-2-methylundecane & 13.81 & $\mathrm{C}_{12} \mathrm{H}_{25} \mathrm{l}$ & 296 & 5.09 \\
\hline 14 & 1,2-Benzenedicarboxylic acid, butyl 2-ethylhexyl ester & 18.13 & $\mathrm{C}_{20} \mathrm{H}_{30} \mathrm{O}_{4}$ & 334 & 0.05 \\
\hline 15 & Phthalic acid, heptyl pentyl ester & 13.32 & $\mathrm{C}_{20} \mathrm{H}_{30} \mathrm{O}_{4}$ & 334 & 0.02 \\
\hline 16 & Heptacosane & 17.21 & $\mathrm{C}_{27} \mathrm{H}_{56}$ & 380 & 0.87 \\
\hline 17 & 2-(Cholest-5-en-3-yloxy) ethyl acetate & 22.93 & $\mathrm{C}_{31} \mathrm{H}_{52} \mathrm{O}_{3}$ & 472 & 0.92 \\
\hline
\end{tabular}

RT Retention time, MW Molecular weight 
Table 2 Minimal inhibitory concentration (MIC in $\mathrm{mg} / \mathrm{mL}$ ) and total activity $(\mathrm{TA})$ in $\mathrm{L}$ of extract, fractions and isolated compounds of Oxyanthus speciosus. (TA in $\mathrm{L}$ is calculated by dividing mass of fraction in $\mathrm{mg}$ (MF) by MIC in $\mathrm{mg} / \mathrm{mL}$ and dividing the answer by 1000)

\begin{tabular}{|c|c|c|c|c|c|c|c|c|c|c|c|c|}
\hline \multirow[t]{3}{*}{ Samples } & \multirow{3}{*}{$\begin{array}{l}\text { Yield } \\
(\%)\end{array}$} & \multirow{3}{*}{$\begin{array}{l}\text { MF } \\
\text { (mg) }\end{array}$} & \multicolumn{10}{|c|}{ Microorganisms } \\
\hline & & & \multicolumn{2}{|c|}{ M. smegmatis } & \multicolumn{2}{|c|}{ M. aurum } & \multicolumn{2}{|c|}{ M. tuberculosis } & \multicolumn{2}{|c|}{ M. fortuitum } & \multirow{2}{*}{$\begin{array}{l}\text { Average } \\
\text { MIC }\end{array}$} & \multirow{2}{*}{$\begin{array}{l}\text { Average } \\
\text { TA inL }\end{array}$} \\
\hline & & & $\overline{M I C}$ & TA & $\mathrm{MIC}$ & TA & $\mathrm{MIC}$ & TA & $\mathrm{MIC}$ & TA & & \\
\hline Extract & $2.99^{\mathrm{a}}$ & 26,340 & $0.08^{\mathrm{a}}$ & 329.3 & $0.06^{\mathrm{a}}$ & 439.0 & $0.17^{\mathrm{a}}$ & 154.9 & 0.078 & 337.7 & 0.097 & 315.2 \\
\hline$F_{1}$ & 2.02 & 750 & 1.25 & 0.6 & 2.5 & 0.3 & 2.5 & 0.3 & 2.5 & 0.3 & 2.19 & 0.3 \\
\hline $\mathrm{F}_{2}$ & 3.15 & 1160 & 0.31 & 3.7 & 0.625 & 1.8 & 0.625 & 1.9 & 0.31 & 3.7 & 1.02 & 2.8 \\
\hline $\mathrm{F}_{3}$ & 1.48 & 550 & 0.15 & 3.7 & 0.31 & 1.8 & 0.31 & 1.8 & 0.31 & 1.8 & 0.27 & 2.2 \\
\hline $\mathrm{F}_{4}$ & 3.08 & 1140 & 0.15 & 7.6 & 0.31 & 3.7 & 0.31 & 3.7 & 0.156 & 7.3 & 0.27 & 5.6 \\
\hline $\mathrm{F}_{5}$ & 1.64 & 610 & 0.15 & 4.1 & 0.31 & 1.9 & 2.5 & 0.2 & 0.625 & 0.9 & 0.78 & 1.8 \\
\hline$F_{6}$ & 0.32 & 120 & 1.25 & 0.09 & 2.5 & 0.048 & 0.625 & 0.2 & 1.25 & 0.1 & 1.25 & 0.1 \\
\hline $\mathrm{F}_{7}$ & 0.43 & 160 & 1.25 & 0.1 & 0.625 & 0.3 & 1.25 & 0.1 & 1.25 & 0.1 & 1.09 & 0.2 \\
\hline$F_{8}$ & 0.81 & 300 & 0.15 & 2 & 0.625 & 0.5 & 2.5 & 0.1 & 1.25 & 0.2 & 1.13 & 0.7 \\
\hline$F_{9}$ & 0.08 & 30 & 0.039 & 0.8 & 0.31 & 0.09 & 0.31 & 0.09 & 0.625 & 0.05 & 0.48 & 0.3 \\
\hline$F_{10}$ & 28.35 & 10,490 & 0.039 & 269 & 0.156 & 67.2 & 0.31 & 33.8 & 0.625 & 16.8 & 0.28 & 96.7 \\
\hline$F_{11}$ & 29.81 & 11,030 & 0.15 & 73.5 & 0.156 & 71 & 0.31 & 35.6 & 0.625 & 17.6 & 0.31 & 33 \\
\hline Rif & nd & nd & 12.5 & nd & 1.56 & nd & 100 & nd & nd & nd & 38.02 & nd \\
\hline Lut & nd & 6.4 & 0.05 & na & 0.013 & na & 0.025 & na & 0.025 & na & 0.028 & na \\
\hline RA & nd & 50 & 0.1 & na & 0.1 & na & 0.1 & na & 0.1 & na & 0.1 & na \\
\hline
\end{tabular}

Ms M. smegmatis, Ma M. aurum, Mt M. tuberculosis, Mf M. fortuitum, $F_{1}-F_{11}$ fractions, nd not determined, na not available, RA Rotundic acid, Rif Rifampicin, Lut Lutein

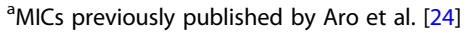

Values in bold indicates MIC and TA of fractions with good activites

microbes. Rotundic acid had a poor selectivity index of 0.33. The selectivity index (SI) of lutein ranged from 4 to > 16, indicating that the cytotoxic activities were higher to mycobacteria than to eukaryotic cells. Caamal-Fuentes et al. [39] stated that the therapeutic index of a drug should be 10 or higher. The two identified compounds isolated from the crude extract of Oxyanthus speciosus, lutein and rotundic acid, dose dependently inhibited NO production at concentrations of 3.12, 6.25, 12.5 and $25 \mu \mathrm{g} / \mathrm{mL}$ (Table 4). Lutein led to the highest percentage inhibition $(94.99 \%)$ at a concentration of $25 \mu \mathrm{g} / \mathrm{mL}$ and a cell viability of $91.59 \%$. The NO inhibitory activity expressed by lutein was therefore not due to a general metabolic toxin.

\section{Intracellular assay}

The intracellular antimycobacterial activities of $O$. speciosus extract and the anti-TB drug rifampicin against M. fortuitum were assessed using RAW 264.7 macrophages. Mouse macrophages were infected with $M$. fortuitum with a multiplicity of infection (MOI) of five mycobacteria per cell. Infection of macrophages at a low MOI leads to phagosomal maturation thereby resulting in inhibition of $M$. tuberculosis growth in the macrophage [40]. The acetone extract of $O$. speciosus were not cytotoxic to RAW 264.7 macrophages even at the highest tested concentration $(1 \mathrm{mg} / \mathrm{mL})$ [27]. The extract significantly decreased the number of intracellular mycobacteria at $0.5 \mathrm{X}, 1 \mathrm{X}, 2 \mathrm{X}$ and $4 \mathrm{X}$ the MIC value of $120 \mu \mathrm{g} /$ $\mathrm{mL}$. The plate was washed with PBS before lysing the cells to avoid false positive results. $M$. fortuitum was effectively phagocytized after the $4 \mathrm{~h}$ incubation period. One unique characteristic of Mycobacterium species is the ability to grow in both intra- and extracellular environments, therefore an ideal antimycobacterial agent should be active in both locales [41]. On day 6 post-infection, the intracellular antimycobacterial activity of the acetone crude extract of O. speciosus at $1 \mathrm{X}$ to $4 \mathrm{X}$ MIC was superior to that of rifampicin, showing more than $90 \%$ reduction in colony forming units. The bactericidal activity observed was both dose and time-dependent. Moderate inhibitory effect was observed for the extracts of O. speciosus at 0.5X MIC inhibiting less than $50 \%$ growth of intracellular bacteria during 6 days of drug exposure (Fig. 3a) compared to that of rifampicin (Fig. $3 \mathrm{~b}$ ) at the same concentration, inhibiting more than $50 \%$ growth of the intracellular mycobacteria.

\section{Discussion}

Discovery of potential lead compounds and their advancement towards drug development involves extraction of the crude extract from source, conducting bioassay-guided fractionation and most importantly the purification process to yield a single bioactive compound 
Table $3 \mathrm{LC}_{50}$ (against C3A liver cells) and selectivity index (SI) values of extract, fractions and compounds of Oxyanthus speciosus

\begin{tabular}{|c|c|c|c|c|c|}
\hline \multirow[t]{2}{*}{ Samples } & \multirow{2}{*}{$\begin{array}{l}\mathrm{LC}_{50} \\
(\mu \mathrm{g} / \\
\mathrm{mL})\end{array}$} & \multicolumn{4}{|l|}{$\mathrm{SI}$} \\
\hline & & $\overline{M s}$ & $M a$ & $M t$ & Mf \\
\hline Extract & $383^{a}$ & $1.24^{\mathrm{a}}$ & $2.46^{\mathrm{a}}$ & $2.25^{\mathrm{a}}$ & 4.91 \\
\hline$F_{1}$ & 40 & 0.03 & 0.02 & 0.02 & 0.02 \\
\hline$F_{2}$ & 34 & 0.11 & 0.05 & 0.05 & 0.11 \\
\hline $\mathrm{F}_{3}$ & 60 & 0.38 & 0.19 & 0.19 & 0.19 \\
\hline $\mathrm{F}_{4}$ & 190 & 1.22 & 0.61 & 0.61 & 1.22 \\
\hline $\mathrm{F}_{5}$ & 200 & 1.28 & 0.65 & 0.08 & 0.32 \\
\hline$F_{6}$ & 70 & 0.06 & 0.03 & 0.11 & nd \\
\hline $\mathrm{F}_{7}$ & 156 & 0.12 & 0.25 & 0.12 & 0.12 \\
\hline $\mathrm{F}_{8}$ & 510 & 3.27 & 0.82 & 0.20 & 0.41 \\
\hline$F_{9}$ & 40 & 1.03 & 0.13 & 0.13 & 0.06 \\
\hline F10 & 50 & 1.28 & 0.32 & 0.16 & 0.08 \\
\hline F11 & 80 & 0.51 & 0.51 & 0.26 & 0.13 \\
\hline Rif & $>200$ & nd & nd & nd & nd \\
\hline Lut & $>200$ & $>4$ & $>16$ & $>8$ & $>8$ \\
\hline RA & 33 & 0.33 & 0.33 & 0.33 & 0.33 \\
\hline Dox & 3.32 & nd & nd & nd & nd \\
\hline
\end{tabular}

[42]. Crude natural product extracts are complex mixtures of perhaps hundreds of different compounds working together in synergy when the extract is administered as a whole. With the exception of $M$. smegmatis (that had an increase of $11 \%$ ) there were substantial losses in the combined total activity of the fractions compared to the crude extract based on the fractionation assay. These losses varied from $86 \%$ (M. fortuitum), 66\% (M. aurum) to $50 \%$ for $M$. tuberculosis. The losses may be explained by inactivation of compounds during the isolation process or alternatively by the loss of synergism between compounds that were separated during the isolation. Therefore, the combined action of two or more substances can result in a biological effect higher than any single one's. Hence, more thorough studies are necessary to find which substances should be mixed in order to attain the desired antimycobacterial activity because the two-fold serial dilution method does not provide accurate results in doubling or halving of the TA which may not be significant. The losses found here are much larger than explicable by inaccurate measurements. It is interesting that there were also large differences in losses between the different pathogens. The results obtained from this study is similar to the study conducted by Ntutela et al., [43] where loss of antimycobacterial activities after fractionation and effect of synergism between fractions were recorded.

Two compounds 2-(2-hydroxy)-ethanol- $\beta$-D-glucopyranoside and a cyanogenic glycoside, halocalin, were isolated from Oxyanthus speciosus subsp. gerrardii and Oxyanthus speciosus subsp. speciosus respectively [44]. Two compounds have been reported to be isolated from Psychotria capensis (Rubiaceae) and have been identified as $\beta$-sitosterol and a carotenoid derivative, lutein [45]. Plant carotenoids are naturally occurring fat-soluble pigments that give bright coloration to plants and have pharmacological properties such as strong antioxidant activity; they are also used for the relief of some chronic diseases like cardiovascular disease, osteoporosis and cancer [46]. Some carotenoids such as $\beta$-carotene, lutein and lycopene can also offer protection against some inflammatory responses [47]. Lutein

Table 4 Inhibitory activities of compounds on NO production in LPS-activated RAW 264.7 macrophages

\begin{tabular}{|c|c|c|c|c|}
\hline Samples & Concentration $(\mu \mathrm{g} / \mathrm{mL})$ & $\begin{array}{l}\text { NO production } \\
(\mu M)\end{array}$ & $\begin{array}{l}\% \mathrm{NO} \\
\text { inhibition }\end{array}$ & $\begin{array}{l}\% \text { cell } \\
\text { viability }\end{array}$ \\
\hline \multirow[t]{4}{*}{ Lutein } & 25 & $0.14 \pm 0.02$ & 94.99 & 91.59 \\
\hline & 12.5 & $0.44 \pm 0.15$ & 83.85 & 92.59 \\
\hline & 6.25 & $1.37 \pm 0.07$ & 49.46 & 86.84 \\
\hline & 3.12 & $1.98 \pm 0.08$ & 27.17 & 74.20 \\
\hline \multirow[t]{4}{*}{ Rotundic acid } & 25 & $0.48 \pm 0.18$ & 82.39 & 87.48 \\
\hline & 12.5 & $1.19 \pm 0.16$ & 56.24 & 86.11 \\
\hline & 6.25 & $2.01 \pm 0.16$ & 26.20 & 78.51 \\
\hline & 3.12 & $2.39 \pm 0.09$ & 12.16 & 73.73 \\
\hline \multirow[t]{4}{*}{ Quercetin } & 25 & $0.35 \pm 0.10$ & 99.35 & 57.60 \\
\hline & 12.5 & $0.30 \pm 0.05$ & 106.61 & 79.23 \\
\hline & 6.25 & $0.69 \pm 0.08$ & 110.49 & 105.03 \\
\hline & 3.12 & $2.50 \pm 0.48$ & 94.50 & 101.23 \\
\hline
\end{tabular}




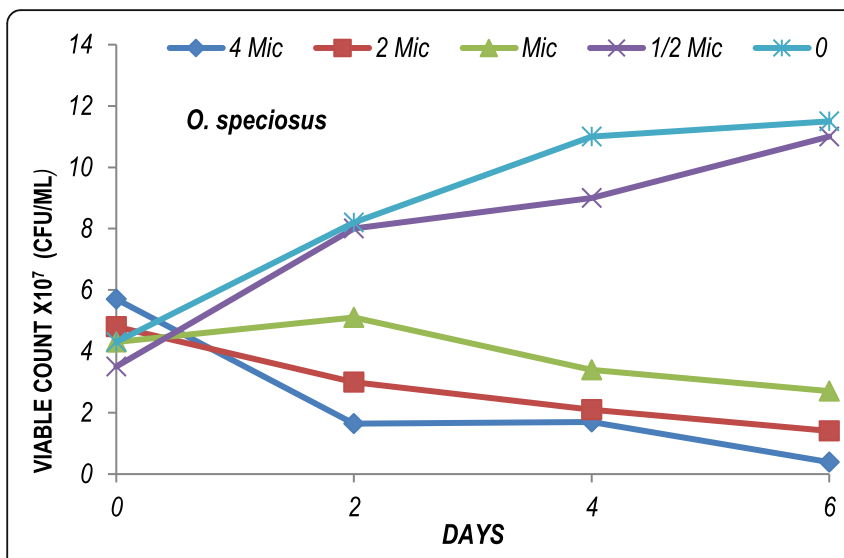

(a)

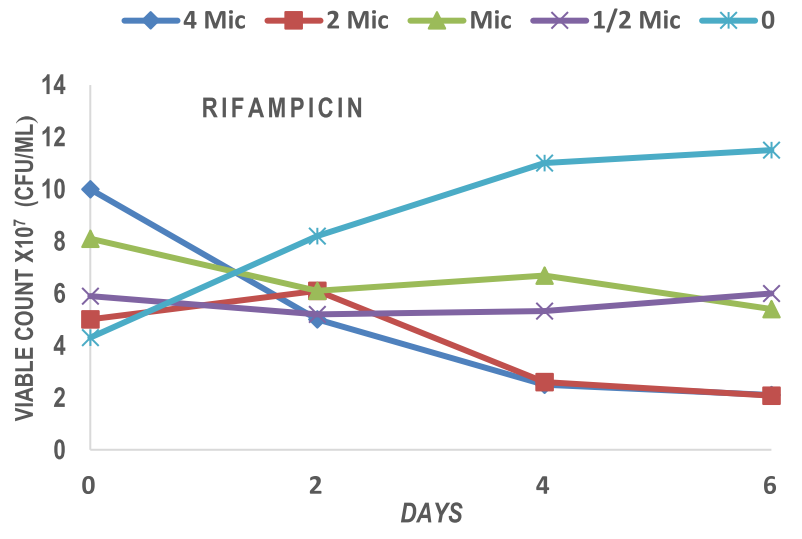

(b)

Fig. 3 RAW 264.7 cells infected with Mycobacterium fortuitum with a MOI 1:5 (cells:bacilli) were exposed to several concentrations of extract and rifampicin $(0.5 \mathrm{X}, 1 \mathrm{X}, 2 \mathrm{X}$ and $4 \mathrm{X} \mathrm{MICS}, 0=$ untreated control) in triplicate. After 2, 4 and 6 days post infection, cells were lysed and plated on $7 \mathrm{H} 10$ agar to determine CFU/mL. Plots detail the bactericidal activity of extract of $O$. speciosus (a) and rifampicin (b) used as the reference positive control antibiotic. Values represent means \pm SD

has been isolated from Tagetes erecta and the plant is used for the treatment of cough and dysentery amongst others [48]. Some of the triterpenes isolated from the Rubiaceae family include oleanolic acid, ursolic acid, lupeol, betulinic acid, rotundic acid, barbinervic acid and luculiaoic acid (A) [20]. Rotundic acid was isolated from the fruit of Ilex rotunda [34]. This ursene-type triterpene was also isolated from the leaves of Guettarda pohliana belonging to the Cinchonoideae subfamily of the Rubiaceae family [49]. Previous reports have suggested that lutein is able to enhance in vitro and in vivo inflammatory responses by suppressing NF- $\mathrm{kB}$ activation $[50,51]$. Therefore, it can be said that lutein plays a significant role in modulating inflammatory processes by regulating cellular redox potential [52]. The results obtained from this study suggest that the antimycobacterial activity exhibited by lutein could occur by inhibiting the production of inflammatory mediators in vivo responsible for the pathogenesis of chronic inflammatory disease such as TB. The ability of the extract to inhibit the replication of mycobacteria intracellularly revealed a noteworthy result. The low MIC value and dose-dependent bactericidal activity observed in the macrophages suggests effective intracellular penetration of the crude extract of O. speciosus. Although this observed inhibitory activity on intracellular mycobacteria was at a higher concentration $\left(\geq 2 \mathrm{X}\right.$ MIC), the $\mathrm{LC}_{50}$ of the crude extracts on the host cells was still higher $(393 \mu \mathrm{g} / \mathrm{mL})$ than this value. Therefore, the host cells would not be too adversely affected at concentrations that are effective against intracellular mycobacteria. The result obtained from this study is similar to the study conducted by Gupta et al., [53] where the acetone crude extract of Alpinia galanga was able to inhibit the replication of Mycobaterium tuberculosis intracellularly. The intracellular killing potential of the acetone extract of O. speciosus to exert its mode of action is of great interest.

\section{Conclusions}

It can be concluded that lutein is one of the active compounds responsible for the antimycobacterial activity in the crude extract of Oxyanthus speciosus. In addition to the promising in vitro antimycobacterial activity and low cytotoxicity to C3A human cells, lutein also had good anti-inflammatory activity. The promising activity of the crude extract of O. speciosus both in vitro and intracellularly in macrophages suggests its potential for use as an anti-TB herbal medicine. However, further studies are necessary to investigate its mechanism of action, bioavailability and in vivo effects. This study also contributes to the validation of the use of non-pathogenic mycobacteria as a model for intracellular study.

\section{Abbreviations \\ BCG: Bacillus-Calmette Guerin; CC: Silica gel column chromatography; FDA: Food and Drug Administration; hex : N-hexane; LOX: Lipoxygenases; MDR: Multiple Drug Resistance; MIC: Minimum Inhibitory Concentration; NO: Nitric Oxide; PRU: University of Pretoria; RO: Reactive Oxygen Species; TA: Total Activity TA - Total Activity; TDR: Totally Drug Resistant; \\ XDR: Extensively Drug Resistant}

\section{Acknowledgements}

The curator of the Lowveld Botanical Garden allowed collection of plant material. Magda Nel and Elsa van Wyk assisted with herbarium voucher preparation.

The Curator of HGW Schweickert Herbarium at the University of Pretoria confirmed the identity of the plant species and saved voucher specimens.

\section{Funding}

This work was supported by the South African Medical Research Council (SIR funding to LJM) and the National Research Foundation (NRF), South Africa. 
Funding was supplied by the National Research Foundation to $\sqcup$ McGaw and JN Eloff (Grant No 81010).

\section{Availability of data and materials}

Data is available from the senior author.

\section{Authors' contributions}

AA did most of the practical work as part of a PhD thesis supervised by LJM and JNE, JPD, MDA and MAS assisted with the isolation and characterization of the active compounds. LJM supervised the whole project and JNE edited the final version and submitted it for publication. All authors read and approved the final manuscript.

\section{Ethics approval and consent to participate}

No ethics approval was required because no experiments on humans or animals were carried out.

\section{Consent for publication}

Not applicable.

\section{Competing interests}

The authors declare that they have no competing interests.

\section{Publisher's Note}

Springer Nature remains neutral with regard to jurisdictional claims in published maps and institutional affiliations.

\section{Author details}

${ }^{1}$ Department of Paraclinical Sciences, Faculty of Veterinary Science, University of Pretoria, Private Bag X04, Onderstepoort 0110, South Africa. ${ }^{2}$ Department of Biochemistry, Faculty of Science, University of Dschang, P.O. Box 67, Dschang, Cameroon. ${ }^{3}$ Laboratory of Natural Products Chemistry, Department of Chemistry, Faculty of Science, University of Dschang, P.OBox 67, Dschang, Cameroon. ${ }^{4}$ Department of Chemistry, University of Pretoria, Pretoria, South Africa.

\section{Received: 14 July 2018 Accepted: 9 May 2019}

Published online: 22 May 2019

\section{References}

1. LoBue PA, Enarson DA, Thoen CO. Tuberculosis in humans and animals: an overview. Int J tuberc lung dis. 2010;14(9):1075-8.

2. Fogel N. Tuberculosis: a disease without boundaries. Tuberculosis. 2015; (95)5:527-531

3. Nguta JM, Appiah-Opong R, Nyarko AK, Yeboah-Manu D, Addo GA. Medicina plants used to treat TB in Ghana. Int J Mycobacteriol. 2015;4(2):116-23.

4. Chahine EB, Karaoui LR, Mansour H. Bedaquiline: a novel diarylquinoline for multidrug-resistant tuberculosis. Ann Pharmacother. 2014;48:107-15.

5. Guzman JD, Evangelopoulos D, Gupta A, Prieto JM, Gibbons S, Bhakta S. Antimycobacterials from Lovage root (Ligusticum officinale Koch). Phytother Res. 2013:27:993-8.

6. Adebayo S, Dzoyem JP, Shai $\amalg$, Eloff JN. The anti-inflammatory and antioxidant activity of 25 plant species used traditionally to treat pain in southern African. BMC Complement Altern Med. 2015:15(1):1-10.

7. Dobrian AD, Lieb DC, Cole BK, Taylor-Fishwick DA, Chakrabarti SK, Nadler JL. Functional and pathological roles of the 12- and 15-lipoxygenases. Prog Lipid Res. 2011;50:115-31.

8. Labuschagné A, Lall N, Mphahlele MJ. Evaluation of structurally related arylquinolines and 2-Aryl-4- methoxyquinolines for potential Antimycobacterial activity. Int Arab J Antimicrob Agent. 2013;3(2):1-12.

9. Bogdan $C$, Rollinghoff $M$, Diefenbach $A$. The role of nitric oxide in innate immunity. Immunol Rev. 2000;173:17-26.

10. Kleinnijenhuis J, Oosting M, Joosten LAB, Netea MG, van Crevel R. Innate immune recognition of Mycobacterium tuberculosis. Clin Dev Immunol. 2011:1-12. https://doi.org/10.1155/2011/405310.

11. Etna MP, Giacomini E, Severa M, Coccia EM. Pro- and anti-inflammatory cytokines in tuberculosis: a two-edged sword in TB pathogenesis. Semin Immunol. 2014;26(6):543-51.

12. Reljic R, Stylianou E, Balu S, Ma JK. Cytokine interactions that determine the outcome of mycobacterial infection of macrophages. Cytokine. 2010;51(1):42-6.
13. Newman DJ, Cragg GM. Natural products as sources of new drugs over the 30 years from 1981 to 2010. J Nat Prod. 2012;75:311-35.

14. Dzoyem JP, Eloff JN. Anti-inflammatory, anticholinesterase and antioxidant activity of leaf extracts of twelve plants used traditionally to alleviate pain and inflammation in South Africa. J Ethnopharmacol. 2015;160:194-201.

15. Kuete V, Efferth T. Cameroonian medicinal plants: pharmacology and derived natural products. Front Pharmacol. 2010;1(10):1-19.

16. Ashforth EJ, Fu C, Liu X, et al. Bioprospecting for antituberculosis leads from microbial metabolites. Nat Prod Rep. 2010;27:1709-19.

17. Adamu M, Naidoo V, Eloff JN. Some southern African plant species used to treat helminth infections in ethnoveterinary medicine have excellent antifungal activities. BMC Complement Altern Med. 2012;12:213.

18. Choudhury KT, Choudhury MD, Baruah M. Anti-bacterial activity of some plants belonging to the family Rubiaceae: a review. World J Pharm Sci. 2012;1:1179-94.

19. Ngwenya NM. Biological and phytochemical screening of major compounds in Cephalanthus natalensis, Thesis submitted for master's in science: University of Johannesburg; 2008.

20. Martins D, Nunez CV. Secondary metabolites from Rubiaceae species. Molecules. 2015;20(7):13422-95.

21. Gurib-Fakeem AB. The-medicinal and aromatic plants of the Indian Ocean Islands. Boca Raton: CRC Press; 2004. p. 331-2.

22. McGaw LJ, Lall N, Meyer JJM, Eloff JN. The potential of south African plants against Mycobacterium infections. J Ethnopharmacol. 2008a;119:482-500.

23. Pauw E, Eloff JN. Which tree orders in southern Africa have the highest antimicrobial activity and selectivity against bacterial and fungal pathogens of animals? BMC Compl and Altern Med. 2014;14:317. https://doi.org/10. $1186 / 1472-6882-14-317$.

24. Aro AO, Dzoyem JP, Hlokwe TM, Madoroba E, Eloff JN, McGaw L. Some south African Rubiaceae tree leaf extracts have antimycobacterial activity against pathogenic and non-pathogenic Mycobacterium species. Phytother Res. 2015;29:1004-10.

25. Mosmann T. Rapid colorimetric assay for cellular growth and survival: application to proliferation and cytotoxicity. J Immunol Methods. 1983;65:55-63.

26. McGaw LJ, Steenkamp V, Eloff JN. Evaluation of Athrixia bush tea for cytotoxity, antioxidant activity, caffeine content and presence of pyrrolizidine alkaloids. J Ethnopharmacol. 2007;110:16-22.

27. Aro AO, Dzoyem JP, Eloff JN, McGaw LJ. Extracts of six Rubiaceae species combined with rifampicin have good in vitro synergistic antimycobacterial activity and good anti-inflammatory and antioxidant activities. BMC Complement Altern Med. 2016;16(1):385-91. https://doi. org/10.1186/s12906-016-1355-y.

28. Rastogi N, Labrousse V, Goh KS. In Vitro activities of fourteen antimicrobial agents against drug susceptible and resistant clinical isolates of Mycobacterium tuberculosis and comparative intracellular activities against the virulent H37Rv strain in human macrophages. Curr Microbiol. 1996;33:67-175.

29. Lall N, Meyer JJM, Wang Y, Bapela NB, van Rensburg CEJ, Fourie B, Franzblau SG. Characterization of intracellular activity of Antitubercular constituents from the roots of Euclea natalensis. Pharm Biol. 2005:43:353-7.

30. Masoko J, Eloff JN. The diversity of antifungal compounds of six south African Terminalia species (Combretaceae) determined by bioautography. Afr J Biotechnol. 2005;4(12):1425-31.

31. Molnar J, Gyemant N, Tanaka M, Hohmann J, Bergmann-Leitner E, Molnar P, Deli J, Didiziapetris R, Ferreira M. Inhibition of multidrug resistance of Cancer cells by natural Diterpenes, triterpenes and carotenoids. Curr Pharm Des. 2006;12(3):287-311.

32. Khachik F, Goli MB, Beecher GR, Holden J, Lusby WR, Tenorio MD, Barrera MR. J Agric Food Chem. 1992:40(3):390-8.

33. Moss GP. Carbon-13 NMR spectra of carotenoids. Pure Appl Chem. 1976;47:97-102

34. Nakatani M, Miyazaki $Y$, Iwashita T, Naoki H, Hase T. Triterpenes from llex rotunda fruits. Phytochemistry. 1989;28(5):1479-82.

35. Eloff JN. Quantification the bioactivity of plant extracts during screening and bioassay guided fractionation. Phytomedicine. 2004;11:370-1.

36. Kuete V. Potential of Cameroonian plants and derived natural products against microbial infections; a review. Planta Med. 2010;76:1479-91.

37. Eloff JN. A proposal on expressing the antibacterial activity of plant extracts - a small first step in applying scientific knowledge to rural primary health care in South Africa. S Afr J Sci. 2000:96:116-8.

38. Rafi MM, Shafaie Y. Dietary lutein modulates inducible nitric oxide synthase (iNOS) gene and protein expression in mouse macrophage cells (RAW 264. 7). Mol Nutr Food Res. 2007;51:333-40. 
39. Caamal-Fuentes E, Torres-Tapia L, Simá-Polanco P, Peraza- Sánchez SR, MooPuc R. Screening of plants used in Mayan traditional medicine to treat cancer-like symptoms. J Ethnopharmacol. 2011;135:719-24.

40. Welin A, Lerm M. Inside or outside the phagosome? The controversy of the intracellular localization of Mycobacterium tuberculosis. Tuberculosis. 2012:92:113-20

41. Pauli GF, Case RJ, Inui T, Wang Y, Cho S, Fischer NH, Franzblau SG New perspectives on natural products in TB drug research. Life Sci. 2005;78:485-94.

42. Nguta JM, Appiah-Opong R, Nyarko AK, Yeboah-Manu D, Addo GA. Review: current perspectives in drug discovery against tuberculosis from natural products. Int J Mycobacteriol. 2015;4(16):5-183.

43. Ntutela S, Smith P, Matika L, Mukinda J, Arendse H, Allie N, Estes DM, Mabusela W, Folb P, Steyn L, Johnson Q, Folk WR, Syced J, Jacobs M. Efficacy of Artemisia afra phytotherapy in experimental tuberculosis. Tuberculosis. 2009;89(1):33-40.

44. Nahrstedt A, Rockenbach J, Wray V. Phenylpropanoid glycosides, a furanone glucoside and geniposidic acid from members of the rubiaceae. Phytochemistry. 1994;39:375-8.

45. Carvalho JT, Perazzo FF, Machado L, Bereau D. Biologic activity and biotechnological development of natural products. Biomed Res Int. 2013; 2013:971745 4 pages.

46. Salminen A, Lehtonen M, Suuronen T, Kaarniranta K, Huuskonen J. Terpenoids: natural inhibitors of NF-kappaB signaling with antiinflammatory and anticancer potential. Cell Mol Life Sci. 2008;65:2979-99.

47. Wen $\mathrm{C}$, Chen $\mathrm{H}$, Yang N. Developing Phytocompounds from medicinal plants as Immunomodulators. Adv Bot Res. 2012;62:197-272.

48. Chengaiah BR, Kumar KM, Alagusundaram M, Chetty CM. Medicinal importance of natural dyes- a REVIEW. Int J PharmTech Res. 2010;2(1):144-54.

49. Testa G, Oliveira PRN, Silva CC, Schuquel ITA, Santin SM, Kato L, Oliveira CMA, Arruda LLM, Bersani-Amado CA. Constituintes químicos das folhas e avaliação da atividade anti-inflamatória de extratos das raízes e folhas de Guettarda pohliana Müll. Arg.(Rubiaceae). Quim Nova. 2012;35:527-9.

50. Lee MH, Lee JM, Jun SH, Lee SH, Kim NW, Lee JH, et al. The antiinflammatory effects of Pyrolae herba extract through the inhibition of the expression of inducible nitric oxide synthase (iNOS) and NO production. J Ethnopharmacol. 2007;112:49-54.

51. Ryu JH, Ahn H, Kim JY, Kim YK. Inhibitory activity of plant extracts on nitric oxide synthesis in LPS-activated macrophages. Phytother Res. 2003;17:485-9.

52. Kim HK, Cheon BS, Kim YH, Kim SY, Kim HP. Effects of naturally occurring flavonoids in nitric oxide production in the macrophage cell line RAW264.7 and their structure-activity relationship. Biochem Pharmacol. 1999;58:759-65.

53. Gupta P, Bhatter P, D'souza D, Tolani M, Daswani P, Tetali P, Birdi T.

Evaluating the anti Mycobacterium tuberculosis activity of Alpinia galanga (L) Willd. axenically under reducing oxygen conditions and in intracellular assays. BMC Complement Altern Med. 2014;14:84-91 http://www. biomedcentral.com/1472-6882/14/84

Ready to submit your research? Choose BMC and benefit from:

- fast, convenient online submission

- thorough peer review by experienced researchers in your field

- rapid publication on acceptance

- support for research data, including large and complex data types

- gold Open Access which fosters wider collaboration and increased citations

- maximum visibility for your research: over $100 \mathrm{M}$ website views per year

At $\mathrm{BMC}$, research is always in progress.

Learn more biomedcentral.com/submissions 